\section{International Scientific Journal Theoretical \& Applied Science}

p-ISSN: 2308-4944 (print) e-ISSN: 2409-0085 (online)

Year: $2015 \quad$ Issue: $05 \quad$ Volume: 25

Published: $30.05 .2015 \quad$ http://T-Science.org
Gaibnazar Khodievich Khojmetov

Doctor of Technical sciences, Professor,

Tashkent Automobile and Road Institute, Uzbekistan

Anvar Sayfullaevich Yuvmitov

researcher,

Tashkent Architectural-Building Institute, Uzbekistan anvar.sayfullaevich@mail.ru diyorbek_84@mail.ru

SECTION 8. Architecture and construction.

\title{
STRESS-STRAIN STATE OF THE SYSTEM «BUILDING - STACK-LIKE STRUCTURE», CONNECTED WITH A DAMPER UNDER SEISMIC EFFECT
}

Abstract: In this work was considered the task influence of the parameters of the damper to the stress-strain state of the system «building - stack-like structure». As an example was given the four-storey large-panel and frame buildings before and after connection with a damper in experimental conditions.

Key words: Kelvin-Voigt model, Damper, The Coulomb's force, Modeling, Similarity multipliers, Dynamic characteristics, Oscillations, Sensors, Accelerogram.

Language: English

Citation: Khojmetov GK, Yuvmitov AS (2015) STRESS-STRAIN STATE OF THE SYSTEM «BUILDING STACK-LIKE STRUCTURE», CONNECTED WITH A DAMPER UNDER SEISMIC EFFECT. ISJ Theoretical \& Applied Science 05 (25): 150-154.

Soi: $\underline{\text { http://s-o-i.org/1.1/TAS*05(25)28 Doi: crossef http://dx.doi.org/10.15863/TAS.2015.05.25.28 }}$

\section{Introduction}

Currently there is a tendency around the world to construct mutually adjacent buildings $[1,2]$. They can be rigidly interconnected. If the connection is done using certain types of dampers (Fig. 1), the amplitude of building oscillations during earthquakes could be significantly reduced, thus decreasing seismic loads. Dampers may be of various types, for example, in [1] seismic response of structures, connected with dampers, working on Maxwell principle is considered, and in [2] - Kelvin-Voigt principle. Such construction, i.e. a structures attached to main buildings, is carried out in neighboring countries, as well as in our Republic.

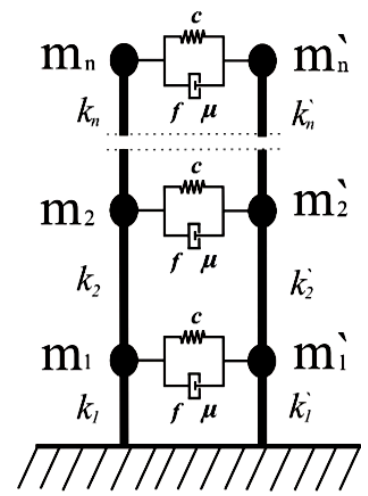

Figure1 - Design scheme of the system "building - stack-like structure" connected with dampers.

$k_{i}, k_{i}{ }_{i}$-coefficients of floor rigidity; $m_{i}, m_{i}$ - floor masses; $c$-coefficient of rigidity of elastic element, $f$-coefficient of dry friction, $\mu$ - coefficient of viscosity of viscous element of a damper

Structure of a damper working according to the principle, shown in Fig. 1 is offered in this work [3].

The structure of connecting element is schematically shown in Fig.2 [4]. It consists of ferroconcrete column base 1 , sand 2, compensator of steel sheet 3, framework as an elastic connection 4 and steel plates 5 . 


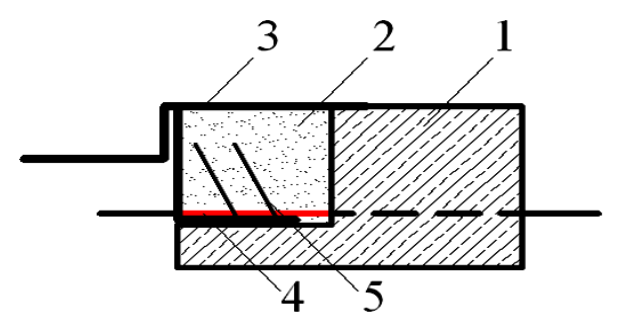

Figure 2 - General view of a damper.

The structure of connecting elements also may be of different types. As an example we may mention the structure of connecting element, offered by Z.M.Klgatyan [5], and others presented in $[6,7,8]$. These connecting elements allow us to regulate in a certain limits amplitude-frequency characteristics of building vibrations and hence seismic loads, occurring in them. Therefore, a connecting element, working by the principle of elastic-viscous connection has been built and tested in model experiments.

One section of 4-storey large-panel and frame house building (Fig.3), modeled on the basis of A.G.Nazarov's theory of expanded similarity [9] was selected as an object. The scale of modeling is $1 / 5$. To prevent cantledge of the model (to compensate the lack of volume forces) accelerations of full-scale experiment and a model are taken as similar ones.

Strength characteristics of field structure and a model, taken for the material of field structure and calculated for a model, are presented in Table 1, where $\mathrm{R}$ - is a cubic strength of concrete; $\mathrm{R}_{\mathrm{pr}}$ - prism strength of concrete; $\mathrm{E}_{0}$ - elasticity modulus of concrete; $\mathrm{R}_{\mathrm{a}}$ - yield strength of a reinforcement; $\mathrm{E}_{\mathrm{a}}$ elasticity modulus of a reinforcement; asterisk refers to a model. Design similarity factors of discussed structure for these values are (Table 2).

Strength characteristics of building material of full-scale field structure and a model.

\begin{tabular}{|c|c|c|c|}
\hline \multirow{2}{*}{ Name of material } & \multirow{2}{*}{ Value and dimension units } & \multicolumn{2}{|c|}{$\begin{array}{c}\text { Ferroconcrete structures, foundations, floor plates, cores, } \\
\text { seismic belts, wall panels brickwork }\end{array}$} \\
\cline { 3 - 4 } & & original & model \\
\hline \multirow{3}{*}{ Ordinary heavy concrete } & $\mathrm{R}, \mathrm{R}^{*} \mathrm{MPa}$ & 20 & 4 \\
& $\mathrm{R}_{\mathrm{pr}}, \mathrm{R}_{\mathrm{pr}}^{*} \mathrm{MPa}$ & 14.5 & 2.9 \\
& $\mathrm{E}_{0}, \mathrm{E}^{*}{ }_{0} \mathrm{MPa}$ & 26500 & 8748.6 \\
& $\lambda_{\mathrm{r}}, \lambda^{*}$ & 0,6 & 0,6 \\
\hline \multirow{2}{*}{ Reinforcement } & $\mathrm{R}_{\mathrm{a}}, \mathrm{R}_{\mathrm{a}}^{*} \mathrm{MPa}$ & 300 & 60 \\
& $\mathrm{E}_{\mathrm{a}}, \mathrm{E}_{\mathrm{a}}^{*} \mathrm{MPa}$ & 210000 & 41500 \\
\hline
\end{tabular}

Similarity factors.

Table 2

\begin{tabular}{|c|c|c|c|}
\hline $\begin{array}{c}\text { Linear dimensions and } \\
\text { stresses }\end{array}$ & $\alpha=\beta=0,2$ & Linear loads & $\alpha^{2} \delta=0,04$ \\
\hline Strains & $\gamma=1$ & Concentrated loads & $\alpha^{3} \delta=0,008$ \\
\hline Time & $\xi=0,45$ & Force moments & $\alpha^{4} \delta=0,0016$ \\
\hline Acceleration & $\alpha \gamma \xi^{-2}=1$ & $\begin{array}{c}\text { Deflections and } \\
\text { displacements }\end{array}$ & $\alpha \gamma=0,2$ \\
\hline
\end{tabular}

Dynamic characteristics of the model of the building and the one with attached structure were determined in tests with offered damper. Vibrations of building model were initiated by two ways: by tension with wire and weight dropping. Accelerations in different points of the building along its height were recorded during the tests. Vibrations were recorded with DYTRON (USA) sensors; their bases 
being piezoelectric elements (Fig.4). Sensors were manufactured to record the signals from one or three components. The signals in the form of a stress via convertor enter into computer. Computer software transforms stress signals into accelerations. The

A

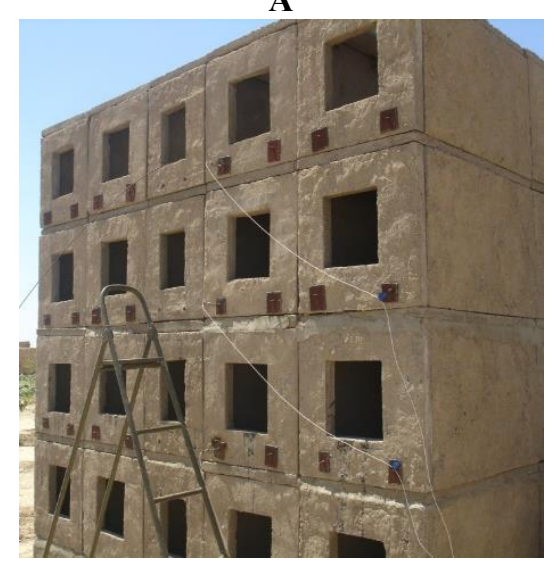

gauges may be adjusted to different frequency ranges. During the tests the computer was adjusted to the frequencies most often observed under micro-seismic oscillations.

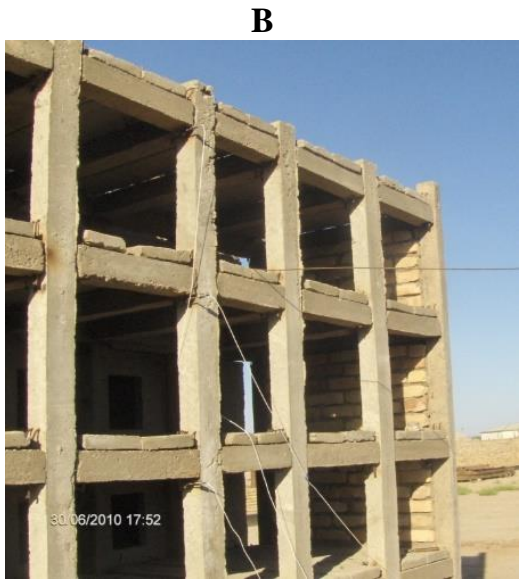

Figure 3 - Model of the section of the building A and model of built stack-like structure B.

$\mathbf{A}$

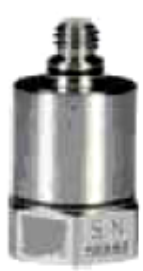

B

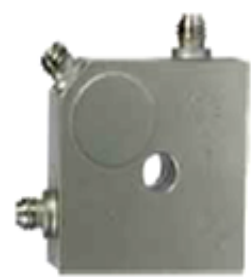

Figure 4 - General view of the one component sensor A on the model 14108 and of the three components sensor $B$ on the model 12500 for recording accelerations.

Experimental results have been translated to full-scale buildings, using the scale of modeling and built spectral densities of «Matlab» program. Before starting serial experiment, preliminary experiments have been conducted, where all floors (except the first) have been connected by connecting elements in different combinations of them. For example, 3, 4 and 5; 3 and 4; 3 and 5; 4 and 5 floors have been connected. These preliminary experiments have shown that the greatest effect is achieved when connecting the third and the fourth floors by viscouselastic coupling. Below are the results of experiments when only the third and the fourth floors are connected by connecting element of "building-stack" system.

According to accelerations records and built spectral densities, floor displacements of "buildingstack" system, connected by proposed connecting element have been determined. For this purpose, the graphs have been built, based on calculated values of maximal amplitudes of oscillations, of dependences of displacements of standing apart building and stack-like structure, and after their connection, that is, "building-stack" system, schematized in the form of a cantilever beam with concentrated masses (Fig.5).

According to normative documents seismic forces, acting on the floors, are determined by console scheme [10]. To estimate stresses occurring in elements of the building as a spatial system is a very complex problem, especially the stresses in panel openings (windows). At present there are different computer software allowing to calculate the building as a spatial system. This allows to determine stresses in any section of any element of the building, especially in openings where stresses are mostly concentrated. This design allows to assess the effect of a damper of «building-stack-like structure» system. Below stress state of studied model of multistorey large-panel and frame house building is determined. It is estimated by known programs Lira Soft and Manomax. Method of Finite Element lies in the bases of these programs. According to the theory of seismic stability the loads acting on the building are considered as applied on floor levels. Inertia force is taken as a load. Results of design and experimental studies are taken as inertia forces. 


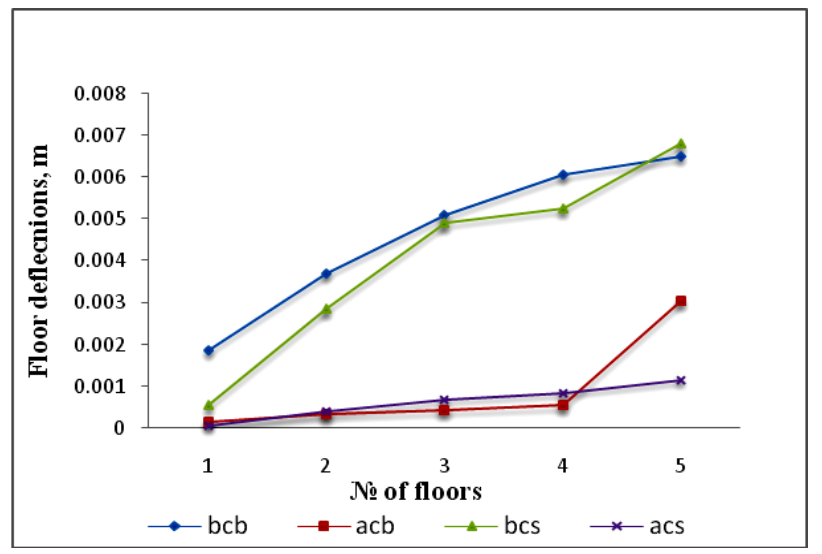

Figure 5 - Floor deflection of adjacent buildings before and after connection with a damper. (bcb, acb and bcs, acs - building and stack-like structure before and after connection with a damper)

Transfer to a model is fulfilled through a coefficient of the theory of similarity. These forces are considered uniformly distributed along the width of building model in the form of stresses, that is, the force is divided on the area equal to a product of building width and floor thickness. Calculated values of given load are presented in Table 3.
Tangential and normal stresses in transverse direction obtained in calculations of the model of large-panel and frame house buildings based on data from Table 1 before and after connection of the system «building-stack-like structure» are shown in Figures 6-7.

\section{Calculated loads for model «building - stack-like structure».}

Table 3

\begin{tabular}{|c|c|c|c|c|c|}
\hline $\begin{array}{c}\text { Model building } \\
\text { (by theory of similarity) }\end{array}$ & $\begin{array}{c}\text { Basement } \\
\text { floor } \\
\left(\mathrm{N} / \mathrm{m}^{2}\right)\end{array}$ & $\begin{array}{c}\text { Ground floor } \\
\left(\mathrm{N} / \mathrm{m}^{2}\right)\end{array}$ & $1^{\text {st }}$ floor $\left(\mathrm{N} / \mathrm{m}^{2}\right)$ & $\begin{array}{c}2^{\text {nd }} \text { floor } \\
\left(\mathrm{N} / \mathrm{m}^{2}\right)\end{array}$ & $\begin{array}{c}3^{\text {rd }} \text { floor } \\
\left(\mathrm{N} / \mathrm{m}^{2}\right)\end{array}$ \\
\hline $\begin{array}{c}\text { Large-panel building before } \\
\text { connection with a damper }\end{array}$ & 43666 & 71916 & 99833 & $1.178^{*} 10^{5}$ & $1.12^{*} 10^{5}$ \\
\hline $\begin{array}{c}\text { Large-panel building after connection } \\
\text { with a damper }\end{array}$ & 38583 & 64333 & 88666 & $1.053 * 10^{5}$ & $1.006^{*} 10^{5}$ \\
\hline $\begin{array}{c}\text { Frame house stack before connection } \\
\text { with a damper }\end{array}$ & 5230 & 29866 & 51200 & 57333 & 55733 \\
\hline $\begin{array}{c}\text { Frame house stack after connection } \\
\text { with a damper }\end{array}$ & 3333 & 19200 & 33066 & 41866 & 36266 \\
\hline
\end{tabular}

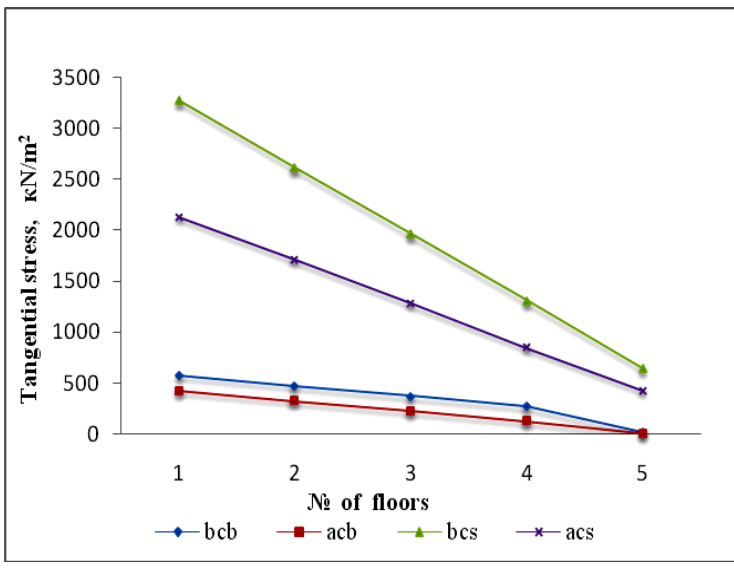

Figure 6 - Tangential stresses of the system before and after connection with a damper. 


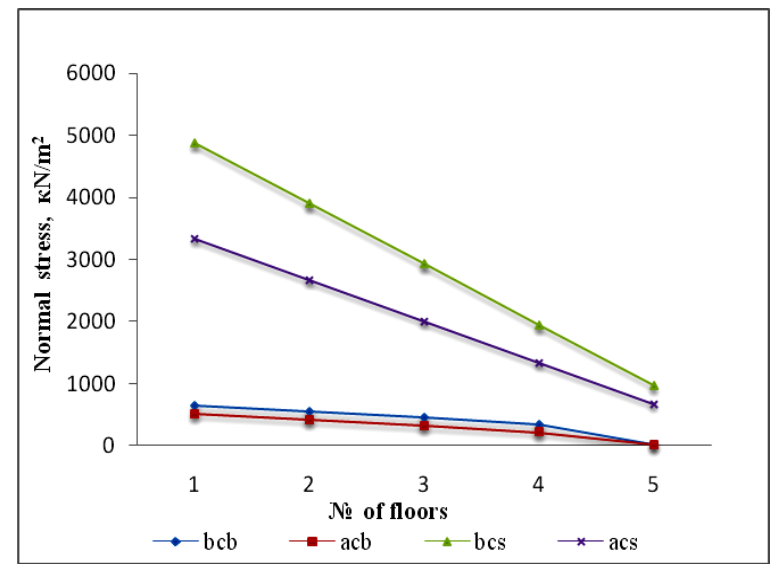

Figure 7 - Normal stresses of the system before and after connection with a damper.

\section{Conclusions}

From Figures 6 and 7 it is seen that the use of connecting element of the type of elastic-viscous connection leads to reduction of occurring stresses in structure elements of adjacent buildings.
So, the application of offered connecting element in the system «building-stack-like structure» together with the solution of the problem of expansion of living space leads to an increase of seismic stability of the building on the whole.

\section{References:}

1. Patel CC, Jangid RS (2010) Seismic response of adjacent structures connected with Maxwell dampers. Asian journal of civil engineering vol.11, №5, 2010 year, pages 585-603.

2. HE Qi, Xu Youlin (1998) Dynamic analysis of damper-connected adjacent buildings under earthquake. Transaction of Tianjin university, vol.4, №2, 1998 year, pages 128-133.

3. Khojmetov GK, Yuvmitov AS (2014) «Conjugation Unit of the System «Buildingattached Structure»»»), Patent of the Republic of Uzbekistan on effective model, №FAP 00973, 03.11.2014.

4. Khojmetov GK, Yuvmitov AS (2014) «Coupling unit of the system «buildingadjacent structure»»!). Patent of the Republic of Uzbekistan on effective model №FAP 00973 03.11.2014.

5. Klgatyan ZM (1999) Seismic-resistant connection for Multi-storey Buildings.-Erevan,
Reports on restoration of 5-storey residential house in Gyumri, 1999.

6. Westermo B (1989) "The dynamics of interstructural connection to prevent pounding." Earthquake Engineering and Structural Dynamics 1989; 18: 687-699.

7. Zhang WS, Xu YL (2000) "Vibration analysis of two buildings linked by Maxwell Modeldefined Fluid Dampers." Journal of Sound and Vibration 2000; 233: 775-796.

8. Hongping Z, Hirokazu I (2000) “A study of response control on the passive coupling element between two parallel structures." Structural Engineering and Mechanics 2000; 9: 383-396.

9. Nazarov AG (1965) On Mechanical Similarity of Rigid Deformable Bodies. - Erevan, Armenian Ac. of Sci,1965.-218p.

10. (1997) Building Code 2.01.03-96 Engineering in Seismic Areas. -Tashkent, 1997. 